\title{
GAYA KEPEMIMPINAN DAN GOOD GOVERNANCE SEBAGAI UPAYA PENINGKATAN EXCELLENT SERVICE DAN KEPERCAYAAN MASYARAKAT \\ (Studi Kasus Dinperindag Jawa Tengah)
}

\section{LEADERSHIP STYLE AND GOOD GOVERNANCE AS AN EXCELLENT SERVICE IMPROVEMENT EFFORTS AND TRUST COMMUNITY}

(Case Study Dinperindag Central Java)

\author{
Kesi Widjajanti \\ Eviatiwi Kusumaningtyas Sugiyanto \\ Universitas Semarang
}

\begin{abstract}
ABSTRAKSI
Tujuan dari penelitian ini adalah menganalisis pengaruh gaya kepemimpinan terhadap penerapan prinsip good governance dalam upaya peningkatan excellent service untuk membangun kepercayaan publik di Dinas Perindustrian dan Perdagangan Jawa Tengah (Dinperindag Jateng). 100 responden digunakan untuk memberikan tanggapan tentang gaya kepemimpinan, penerapan prinsip good governance, kinerja pelayanan serta memberikan penilaian tingkat kepercayaannya terhadap Dinperindag Jateng. Selain itu informan kunci dalam penelitian ini digunakan untuk menjustifikasi tanggapan atau pendapat dari para responden tersebut. Alat analisis yang digunakan adalah mix methode dengan desain Sequential Explanatory. Model sequential explanatory dicirikan dengan melakukan pengumpulan data dan analisis data kuantitatif pada tahap pertama, dan diikuti dengan pengumpulan dan analisis data kualitatif pada tahap kedua, guna memperkuat hasil penelitian kuantitatif. Hasil Analisis menunjukkan bahwa secara garis besar masyarakat menilai implementasi dari good governance dan gaya kepemimpinan di lingkungan Dinperindag telah dinilai baik. Dinperindag telah mampu menciptakan pelayanan yang baik bagi masyarakat dan kepercayaan masyarakat terhadap Dinperindag-pun dinilai cukup tinggi. Hasil lain yang diperoleh yaitu 1) kepemimpinan transformasional dapat mempengaruhi pelaksanaan dan implementasi good governance serta memberikan kepercayaan kepada masyarakat, 2) masa kepemimpinan yang pendek belum dapat membuktikan dampak dari gaya kepemimpinan terhadap kinerja pelayanan, 3) kinerja pelayanan yang baik akan membawa kepercayaan masyarakat, 4) pelaksanaan prinsip good governance dapat menciptakan excellent service untuk selanjutnya membawa kepercayaan terhadap masyarakat.
\end{abstract}

Kata Kunci: Gaya Kepemimpinan, Good Governance, Kinerja Pelayanan, Kepercayaan Publik

\section{ABSTRACT}

The aim of this research was to analyze the influence of leadership style on the application of good governance in order to improve excellent service and build public trust in the Department of Industry and Trade of Central Java (Dinperindag Jateng). 100 respondents used to provide feedback about the leadership style, the application of good governance, service performance and provide an assessment of the level of public trust against Dinperindag Jateng. In addition key informants in this study were used to justify the responses or opinions of the respondents. The analytical tools of this research is mix methods with Sequential Explanatory design. Sequential explanatory models are characterized by data collection and analysis of quantitative data in the first stage, followed by the collection and analysis of qualitative data in the second stage, in order to reinforce the results of quantitative research. The results show that public broadly assess the implementation of good governance and leadership style in Dinperindag been rated good. Dinperindag has been able to create a good service for public and public trust in the Dinperindag was considered quite high. Other results were obtained: 1) transformational leadership can affect the execution and implementation of good governance and give trust to the public, 2) the short period of leadership is not able to prove the impact of leadership style on service performance, 3) excellent service will bring public trust, 4) the implementation of good governance principles can create excellent service to further bring public trust.

Key Words: Leadership Style, Good Governance, Excellent Service, Public Trust 


\section{PENDAHULUAN \\ LATAR BELAKANG MASALAH}

Organisasi publik adalah organisasi yang didirikan untuk memenuhi kebutuhan masyarakat akan jasa dan layanan publik. Organisasi ini bertujuan untuk melayani kebutuhan masyarakat demi kesejahteraan sebagaimana di amanatkan dalam konstitusi sebagai pijakan dalam operasionalnya. Organisasi publik dibuat oleh publik, untuk publik dan karenanya harus bertanggung jawab terhadap publik. Dalam kaitanya tersebut, organisasi publik ditantang untuk memenuhi harapan berbagai kelompok stakeholder khusunya penerima layanan yaitu masyarakat. Isu mengenai kualitas layanan cenderung menjadi semakin penting dalam menjelaskan kinerja organisasi pelayanan publik. Banyak pandangan negatif yang terbentuk mengenai organisasi publik muncul karena ketidakpuasan masyarakat terhadap kualitas layanan yang diterima dan organisasi publik.

Tuntutan masyarakat akan pelayanan publik yang berkualitas, mengharuskan pembenahan dalam manajemen publik. Masih tingginya tingkat keluhan masyarakat pengguna jasa menunjukkan bahwa pemerintah sebagai organisasi publik masih belum sepenuhnya mampu menciptakan sistem pelayanan yang akseptabel dimata rakyat. Hal ini sedikit banyak telah membawa dampak menurunnya kepercayaan publik terhadap organisasi publik. Pelayanan publik yang jelek akan mengurangi kepercayaan masyarakat dan memunculkan sikap sinisme Rakyat. Satu tahap penting yang harus dilakukan pemerintah pada saat ini adalah membangun kepercayaan masyarakat terhadap kinerja pemerintah.

Sebagai upaya untuk membentuk, mewujudkan, serta meningkatkan kepercayaan publik kepada pemerintah diperlukan tata kelola pemerintah yang baik, dikelola secara partisipasif dan berdampingan antara masyarakat dengan pemerintah. Konsep-konsep good governance dikembangkan sebagai evaluasi tata kelola pemerintah untuk meningkatkan public trust. Prinsip-prinsip akuntabilitas, transparansi, partisipasi, kesetaraan, keadilan, dan integritas sebagai pendorong peningkatan kepercayaan publik. Menurut Hamka (2007), beberapa poin penting yang terkait dengan implementasi prinsipprinsip Good Governance merupakan pegangan bagi birokrasi publik dalam melakukan transformasi manajemen pemerintahan

Kepemimpinan dalam suatu organisasi menjadi ujung tombak keberhasilan tujuan pemerintah. Keberhasilan penyelenggaraan reformsi birokrasi ditentukan oleh keberadaan seorang pemimpin didalamnya, dengan berbagai karakter yang melekat dan tanggung jawab yang yang dipikulnya, menuntut pemimpin lebih agresif dalam berinovasi dan berkontribusi terhadap proses perubahan yang diharapkan. Dalam mewujudkan pelayanan prima, seorang pemimpin harus berani melakukan perubahan. Karena itu diperlukan kepemimpinan transformasional yaitu kepemimpinan yang mampu sebagai agen perubahan. Disini jelas adanya peran pemimpin sebagai agen perubahan yang akan mengarahkan bawahannya untuk berkinerja tinggi dan meningkatkan kualitas pelayananya terhadap masyarakat.

Pemerintah Daerah Provinsi, Kabupaten dan Kota di Jawa Tengah pada tahun 2014 ini telah menempati rangking pertama terjelek dalam hal pelayanan publik di Jawa Tengah. Hal ini sebagaimana diungkapkan Kepala Ombusmen Jawa Tengah, Akhmad Zaid dalam paparannya di acara Gatering Konco Ombusmen Jateng (Sabtu, 29/11). Pada tahun 2014 ini Instansi Pemerintah Daerah telah menempati rangking terjelek dalam pelayanan publik di Jawa Tengah, dibanding Polri dan BPN. Ditambahkan oleh Zaid, penilaian kinerja layanan didasarkan atas aduan masyarakat yang masuk ke ombusmen sebanyak 140 kasus yang hampir 40 persennya kecewa atas pelayanan pemda, sedangkan 30 persen kecewa layanan polri dan 20 persen terkait layanan di Badan Pertanahan Nasional. Indikator buruknya pelayanan publik yang terlalu lama terkait perizinan. Selain itu, komposisi SDM tidak berkompeten dalam bidang. Dengan begitu, masyarakat merasa dirugikan terkait proses perizinan bertele-tele (Dazuki, 2014) dan bahkan tidak sedikit warga harus menguras kocek rupiah agar dilayani dengan cepat dan kilat (kabar65.com, 2014).

Lebih lanjut Maas (2010) menjelaskan bahwa cerminan dari kualitas pelayanan yang rendah diantaranya dapat dilihat dari pengurusan perizinan usaha yang berbelit-belit, tumpang tindih dan birokratis, kurang jelasnya waktu dan biaya pengurusan perizinan, serta standar pelayan yang belum tersedia.

Dari latar belakang tersebut di atas yaitu pentingnya membangun kepercayaan masyarakat, peningkatan pelayanan publik melalui tata kelola pemerintahan yang baik (good governance), menjadi daya tarik peneliti untuk melakukan penelitian tentang sejauh mana penerapan prinsipprinsip good governance diaplikasikan. Dan tentunya diteliti pula bagaimana gaya kepemimpinan dalam suatu institusi dalam mendukung upaya-upaya tersebut. Sehingga masalah penelitian yang diajukan adalah bagaimana meningkatkan execellent service dan kepercayaan publik melalui penerapan prinsip-prinsip good governance dan gaya kepemimpinan.

Dinas Perindustrian dan Perdagangan Jawa Tengah (Dinperindag Jateng), menjadi obyek dalam penelitian ini, karena berdasarkan data yang 
telah disampaikan sebelumnya bahwa Jawa Tengah menduduki peringkat terjelek pelayanan publik di tahun 2014, indikator dan cerminan terjelek dalam pelayanan yaitu terkait dengan perijinan. Dinperindag Jateng merupakan organisasi publik yang banyak memberikan pelayanan di bidang perijinan. Pelayanan-pelayanan perijinan di lingkup Dinperindag antara laian SKA (Surat Keterangan Asal) Barang/ certificate of origin, API (Angka Pengenal Importir), SIUP (Surat Ijin Usaha Perdagangan), Klinik Manajemen Mutu (sertifikasi SNI, ISO, Barcode), IUI (Ijin Usaha Industri) dan NRP (Nomor Regristasi Produk). Sehingga lebih jelasnya penelitian ini berusaha menganalisis bagaimana gaya kepemimpinan dan Good Governance dilaksanakan sebagai upaya untuk meningkatkan Excellent Service dan membangun kepercayaan masyarakat di lingkungan Dinperindag Jawa Tengah

\section{Rumusan Masalah}

Bagaimana gaya kepemimpinan dan Good Governance dilaksanakan sebagai upaya untuk meningkatkan Excellent Service dan membangun kepercayaan masyarakat di lingkungan Dinperindag Jawa Tengah

\section{KAJIAN PUSTAKA}

Teori ekpektansi (expectancy theory) menurut Victor Vroom yang dikutip oleh Antarwiyati (2006) didasarkan pada ide bahwa tiap orang memiliki ekspektansi (harapan yang kuat). Jika suatu objek mendukung dalam pencapaian tujuan, maka suatu individu akan menunjukan sikap senang terhadap objek tersebut. Masyarakat akan memberikan kepercayaan atau tanggapan yang positif terhadap organisasi publik jika organisasi publik tersebut memenuhi harapannya terkait dengan pelayanan yang dibutuhkan. Pemenuhan harapan masyarakat akan pelayanan yang prima dipengaruhi oleh bagaimana organisasi itu dikelola dengan baik atau buruk serta bagaimana sistem kepemimpinan yang dijalankan.

\section{Kepemimpinan dan Gaya Kepemimpinan}

Sanapiah (2014) mendefinisikan kepemimpinan sebagai suatu proses dimana seseorang mempengaruhi kebiasaan orang lain ke arah penyelesaian tujuan yang spesifik yang mengarah kepada teaching organization untuk dapat melatih dan mengembangkan knowledge, skill, dan attitude setiap individu dalam organisasi. Kualitas kepemimpinan dalam berbagai bentuk memperlihatkan perbedaan antara organisasi yang mampu mencapai tujuan dan yang tidak. Peran pemimpin sebagai agen perubahan yaitu harus mampu mengembalikan kepercayaan masyarakat terhadap manajemen dan pengelolaan birokrasi. Dalam mewujudkan pelayanan prima, seorang pemimpin harus berani melakukan perubahan. Karena itu diperlukan kepemimpinan transformasional yaitu kepemimpinan yang mampu sebagai agen perubahan.

Kepemimpinan transformasional sebagai gaya kepemimpinan yang dapat membangkitkan motivasi karyawan, sehingga dapat berkembang dan mencapai kinerja pada tingkat yang tinggi, melebihi dari apa yang mereka perkirakan sebelumnya. Bass et.al (2003) serta Humphreys (2002) menjelaskan kemampuan seorang pemimpin transformasional dapat mengubah sistem nilai bawahan demi mencapai tujuan diperoleh dengan mengembangkan salah satu atau seluruh faktor dimensi kepemimpinan transformasional, yaitu: pengaruh ideal (idealized influence), motivasi inspirasi (inspiration motivation), pengembangan intelektual (intellectual stimulation), dan perhatian pribadi (individualized consideration).

\subsection{Good Governance}

Good Governance merupakan bentuk dari penyelenggaraan suatu organisasi untuk mencapai tujuan berdasarkan prinsip-prinsip tata kelola yang baik. Beberapa prinsip mengenai good governance diantaranya oleh Organisation for Economic Cooperation and Development (OECD) yaitu: Fairness, Transparency, Accountability, dan Responsibility. Forum for Corporate Governance in Indonesia (FCGI) mengungkapkan prinsipprinsip good governance menjadi Fairness, Disclosure, Transparency, Accountability, dan Responsibility. Menteri Negara BUMN mengungkapkan Prinsip-prinsip good governance menjadi: Fairness, Independency, Transparency, Accountability, dan Responsibility.

Sedangkan menurut Keputusan Menteri Pendayagunaan dan Aparatur Negara (MenPAN) Nomor 63/KEP/M.PAN/7/2003 asas pelayanan publik dengan prinsip-prinsip good governance adalah transparansi, akuntabilitas, kondisional, partisipasif, kesamaan hak dan kesimbangan hak dan kewajiban. Dalimunthe (2010) menggunakan prinsip transparansi, akuntabilitas, keadilan, dan partisipasi sebagai indikator Good Governance.

Menurut Hamka (2007), beberapa poin penting yang terkait dengan implementasi prinsipprinsip Good Governance merupakan pegangan bagi birokrasi publik dalam melakukan transformasi manajemen pemerintahan. Menurut Tjokroamidjojo dalam Hamka (2007), tuntutan ke arah Good Governance juga lahir akibat kualitas pelayanan publik yang rendah. Lebih jauh disebutkan bahwa Good Governance berintegritas dari pelaksanaan pemerintahan. Adapun prinsip yang harus diperhatikan adalah akuntabilitas, 
transparansi, keterbukaan, aturan hukum, perlakuan yang adil (jaminan fairness).

\section{Pelayanan Publik dan Excellent Service Pelayanan Publik}

Pelayanan publik atau pelayanan umum dapat didefinisikan sebagai segala bentuk jasa pelayanan, baik dalam bentuk barang publik maupun jasa publik yang pada prinsipnya menjadi tanggung jawab dan dilaksanakan oleh Instansi Pemerintah di Pusat, di Daerah, dan di lingkungan Badan Usaha Milik Negara atau Badan Usaha Milik Daerah, dalam rangka upaya pemenuhan kebutuhan masyarakat maupun dalam rangka pelaksanaan ketentuan peraturan perundang-undangan (Marzal, 2014).

\section{Excellent Service}

Pelayanan prima atau excellent service adalah pelayanan yang sangat baik dan atau pelayanan yang terbaik, sesuai dengan standar yang berlaku atau dimiliki oleh instansi yang memberi pelayanan sehingga mampu memuaskan pihak yang dilayani (pelanggan) (LAN-RI2004 dalam Brawijaya, 2013). Pelayanan prima atau service excellence adalah suatu sikap atau cara karyawan dalam melayani pelanggan secara memuaskan". Pelayanan prima merupakan suatu pelayanan terbaik, melebihi, melampaui, mengungguli pelayanan yang diberikan pihak lain atau daripada pelayanan waktu yang lalu.

Menurut Parasuraman dalam Abror, 2008 kinerja pelayanan publik yang baik dapat dilihat melalui berbagai indikator yaitu Keandalan (reliability), Daya tanggap (responsiveness), Jaminan (assurance), Perhatian (emphaty) dan Kenyataan (tangibility). Menurut KepMenPan No.KEP/25/M.PAN/2/2004, excellent atau tidaknya pelayanan publik dapat dilihat dengan menggunakan IKM (Index Kepuasan Masyarakat). IKM merupakan data dan informasi tentang tingkat kepuasan masyarakat yang diperoleh dari hasil pengukuran secara kuantitatif dan kualitatif atas pendapat masyarakat dalam memperoleh pelayanan dari aparatur penyelenggara pelayanan publik dengan membandingkan antara harapan dan kebutuhannya.

\section{Kepercayaan (Trust)}

Trust atau Kepercayaan didefinisikan oleh Moorman, Deshpande, dan Zaltman dalam Jahroni (2008) sebagai keinginan untuk menggantungkan diri pada mitra bertukar yang dipercayai. Kepercayaan adalah kesediaan pihak tertentu terhadap pihak lain dalam melakukan hubungan transaksi berdasarkan suatu keyakinan bahwa pihak yang dipercayainya tersebut akan melakukan tindakan sesuai dengan yang diharapkan
(Rahmawaty, 2009). Gefen dalam Yeni (2012) mendefinisikan trust adalah kemauan untuk membuat dirinya peka pada tindakan yang diambil oleh orang yang dipercayainya berdasarkan pada rasa kepercayaan dan tanggung jawab. Dengan demikian kepercayaan adalah kesediaan pihak tertentu menjalin kemitraan dengan pihak lain dengan dasar keyakinan dan tanggung jawab.

Menurut Mayers dalam Putri (2012) faktor yang membentuk kepercayaan seseorang terhadap yang lain ada tiga yaitu kemampuan (ability), kebaikan hati (benevolence), dan integritas (integrity). Mayers et al, yang menjelaskan bahwa faktor pembentuk kepercayaan terdiri dari:

a. Kemampuan (ability)

Kemampuan pemberi layanan untuk melaksanakan kebutuhan dari pelanggan..

b. Kebaikan hati (benevolence)

Benevolence adalah perhatian dan motivasi untuk bertindak sesuai dengan kepentingan konsumen/pelanggan oleh penyedia layanan.

c. Integritas (integrity)

Integritas adalah kejujuran dan kemampuan menepati janji dari pihak yang dipercaya (pemberi layanan).

Kepercayaan konsumen adalah persepsi dari sudut pandang konsumen akan keandalan pemberi layanan dalam pengalaman dan terpenuhinya harapan dan kepuasan konsumen. Kepercayaan ada ketika konsumen memiliki keyakinan terhadap integritas, benevolence, dan ability dari pemberi layanan.

\section{Hubungan Logis Antar Variabel \\ Hubungan Gaya Kepemimpinan dengan Good Governance}

Hayat (2014) menjelaskan bahwa kepemimpinan menjadi tonggak keberhasilan dari reformasi birokrasi dalam pelayanan publik terhadap tujuan good governance. Kepemimpinan bangsa yang tegas dalam kebijakan strategis, transparan efektivitas dan efisiensi, akuntabilitas dalam tugas dan wewenang, disertai dengan pola komunikasi dan relasi secara populis, baik dan adil menjadi tolak ukur tercapainya tujuan reformasi birokrasi dengan good will yang dilakukan secara bersamasama dalam service oriented sebagai fungsi utama dari birokrasi yang berorientasi kepada good governance. Prinsip-prinsip kepemimpinan dalam pelaksanaan reformasi birokrasi menjadi tuntutan yang harus terus dilakukan dan digerakkan sebagai pemacu keberhasilan pemerintahan secara makro menuju good governance. Sehingga hipotesis pertama dalam penelitian ini adalah:

$\begin{array}{ll}\text { Hipotesis } & 1 \quad \text { : Gaya } \\ & \begin{array}{c}\text { Kepemimpinan } \\ \text { Governance }\end{array}\end{array}$




\section{Hubungan Gaya Kepemimpinan dengan Excellent Service}

Kepemimpinan merupakan suatu proses dimana seseorang (atasan) mempengaruhi orang lain (bawahan) untuk bersama-sama mencapai tujuan. Sumber dari pengaruh bisa berupa pengaruh formal yang telah ditetapkan secara organisasional sehingga seorang pemimpin mampu mempengaruhi orang lain semata-mata karena kedudukan di tingkat manajerial (Sanapiah, 2007). Tanpa kepemimpinan yang baik, akan sulit bagi organisasi publik untuk mencapai tujuannya, yaitu memenuhi tuntutan pelaksanaan tugas dan fungsinya yang strategis dalam pelayanan publik. Setiap kegiatan yang menyangkut tugas dan fungsi pokok birokrasi publik menjadi tanggungjawab pimpinan. Lemahnya kualias dan kompetensi pimpinan birokrasi berdampak terhadap kinerja pegawai dan pelayanan publik (Hayat, 2014).

\section{Hipotesis 2 : Gaya Kepemimpinan Berpengaruh terhadap Excellent Service.}

\section{Hubungan Gaya Kepemimpinan dengan Trust}

Sanapiah (2007) menjelaskan bahwa peran pemimpin dalam membangun kepercayaan publik mencakup lingkup internal yang berkaitan dengan upaya menggerakkan dan memastikan seluruh sumberdaya aparatur berkinerja tinggi, dan lingkup eksternal organisasi dalam upaya mencermati harapan masyarakat dan komunikasi eksternal baik menyangkut ukuran-ukuran kinerja pelayanan (public service measures) yang ditetapkan, upaya yang telah, sedang dan akan dilakukan, maupun kinerja pelayanan yang telah dihasilkan. Dalam membangun kepercayaan masyarakat dibutuhkan pemimpin yang berkinerja tinggi dan mampu melakukan pendekatan kepada masyarakat untuk mengakomodasi tuntutan kebutuhan dan permasalahan yang ada dalam masyarakat. Jadi tumbuhnya kepercayaan masyarakat akan tergantung pada kepemimpinan yang dilaksanakan, apakah pendekatan kepada masyarakat yang mereka lakukan berjalan dengan efektif atau kepemimpinan tersebut gagal dalam menjalin hubungan dengan masayarakat. Sehingga hipotesis ketiga dalam penelitian ini adalah:

\section{Hipotesis 3 : Gaya Kepemimpinan Berpengaruh terhadap Trust}

\section{Hubungan Good Governance dengan Excellent Service}

Penerapan prinsip-prinsip Good University Governance (GUG) dalam pengelolaan pelayanan menjadi suatu tuntutan utama terhadap peningkatan kinerja pelayanan. Surya dalam Dalimunthe (2010) menjelaskan bahwa mutu dan kualitas pelayanan menjadi lebih baik dan memuaskan dan tidak menimbulkan keluhan masyarakat dalam menerima pelayanan setelah adanya penerapan prinsip-prinsip good corporate governance. Penyelenggaraan pemerintahan yang baik, adalah pemerintah yang dekat dengan masyarakat dan dalam memberikan pelayanan harus sesuai dengan kebutuhan masyarakat. Esensi kepemerintahan yang baik (good governance) dicirikan dengan terselenggaranya pelayanan publik yang baik, hal ini sejalan dengan esensi kebijakan desentralisasi dan otonomi daerah yang ditujukan untuk memberikan keleluasaan kepada daerah mengatur dan mengurus masyarakat setempat, dan meningkatkan pelayanan publik (Khafid, 2011). Dalam penelitiannya, Barus (2011) menemukan bahwa pengaruh pelaksanaan good governance sangat tinggi terhadap pelayanan publik. Paradigma good governance menjadi relevan dan menjiwai kebijakan pelayanan publik di era otonomi daerah yang diarahkan untuk meningkatkan kinerja manajemen pemerintahan, mengubah sikap mental, perilaku aparat penyelenggara pelayanan serta membangun kepedulian dan komitmen pimpinan daerah dan aparatnya untuk memperbaiki dan meningkatkan pelayanan publik yang berkualitas (Ahmad, 2009). Dari uraian tersebut di atas penerapan prinsip good governance yang baik akan membawa pada peningkatn kualitas pelayanan, sehingga hipotesis ke-empat dalam penelitian ini adalah:

Hipotesis 4 : Good Governance Berpengaruh terhadap Excellent Service

\section{Hubungan Good Governance dengan Trust}

Penerapan Good Corporate Governance (GCG) pada perusahaan merupakan suatu konsep yang digunakan guna menjaga konsistensi dan kepercayaan masyarakat terhadap perusahaan. Penerapan prinsip good corporate governance secara konsisten dan berkesinambungan, dapat menghasilkan suatu kepercayaan publik (Nurcahyani, 2012). Penerapan prinsip good governance akan membawa pada kepercayaan stakeholder. Kepercayaan terhadap kemampuan institusi muncul karena dalam penerapan good governance ada pembagian wewenang dan tanggung jawab yang jelas diantara peserta yang terlibat, serta sesuai dengan kompetensi masingmasing. Budi Santoso, anggota Ombudsman RI, (2014) mengatakan, diperlukan integritas, akuntabilitas, dan transparansi sebagai pendorong meningkatkan kepercayaan publik. Dalam konteks tersebut tersirat bahwa prinsip-prinsip dari good governance merupakan hal yang penting dalam pembentukan dan peningkatan public trust. Nilainilai yang bercirikan good governance akan membangkitkan kepercayaan, dalam pelaksanaan government yang buruk akan membawa pada 
penurunan kepercayaan publik terhadap pemerintah. Sehingga hipotesis kelima dalam penelitian ini adalah:

\section{Hipotesis 5 : Good Governance Berpengaruh terhadap Trust}

\section{Hubungan Excellent Service dengan Trust}

Kepercayaan publik tumbuh dari pelayanan yang berkualitas. Hal tersebut sejalan dengan pernyataan OECD (2000) bahwa pada dasarnya pelayanan publik adalah kepercayaan publik. Menurut Sanapiah (2007) kualitas pelayanan publik merupakan salah satu strategic issue bagi aparatur negara yang harus diaktualisasikan dalam kerangka membangun kepercayaan publik.

Garbarino dan Jhonson dalam Jahroni (2009), menyatakan bahwa kepercayaan sebagai keyakinan konsumen akan kualitas dan keandalan pelayanan yang ditawarkan oleh suatu organisasi. Kepercayaan masyarakat akan tumbuh jika suatu organisasi memberikan kepastian, meningkatkan kualitas, dan kinerja pelayanan sesuai dengan kebutuhan masyarakat dan selaras dengan kemampuan penyelenggara layanan (Brawijaya, 2013). Sehingga hipotesis ke-enam adalah

Hipotesis 6 : Good Governance Berpengaruh terhadap Trust

\section{Kerangka Penelitian}

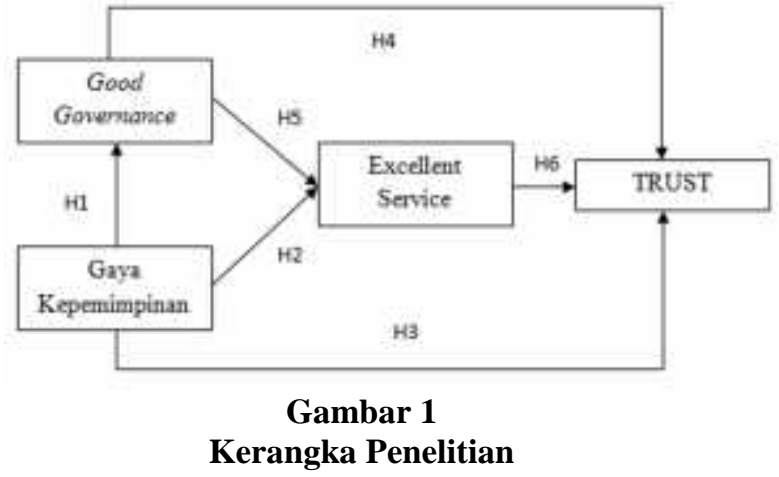

METODE PENELITIAN

Penelitian ini adalah penelitian Mix Methode dengan model Sequential Explanatory Design yang dicirikan dengan melakukan pengumpulan data dan analisis data kuantitatif pada tahap pertama, dan diikuti dengan pengumpulan dan analisis data kualitatif pada tahap kedua, guna memperkuat hasil penelitian kuantitatif yang dilakukan pada tahap pertama (Sugiyono, 2011).

\section{Analisis Kuantitatif}

Metode yang digunakan adalah Structural Equation Modeling (SEM) dengan menggunakan program Partial Least Square (PLS).

Populasi dan Sampling
Populasi dalam penelitian ini adalah masyarakat Jawa Tengah yang telah menggunakan jasa Dinperindag di bidang perijinan. Sampling menggunakan maximum likelhood dengan jumlah sample 100 orang responden

\section{Variabel dan Indikator}

Tabel 1. Variabel dan Indikator

\begin{tabular}{|c|c|c|c|}
\hline No & Variabel & Indikator & Sumber \\
\hline 1. & $\begin{array}{l}\text { Gaya } \\
\text { Kepemimpin } \\
\text { an } \\
\text { (Transformat } \\
\text { ional } \\
\text { Leadership) }\end{array}$ & $\begin{array}{l}\text { - Idealized } \\
\text { Influence } \\
\text { (Kharisma) } \\
\text { - Motivasi } \\
\text { Inspirasional } \\
\text { - Stimulasi } \\
\text { Intelektual } \\
\text { - Pertimbangan } \\
\text { Individual }\end{array}$ & $\begin{array}{l}\text { Bass et } \\
\text { al } \\
\text { dalam } \\
\text { Sonni } \\
(2013)\end{array}$ \\
\hline 2. & $\begin{array}{l}\text { Good } \\
\text { Governance }\end{array}$ & $\begin{array}{l}\text { - Partisipasi } \\
\text { - Accountability } \\
\text { - Transparancy } \\
\text { - Equity }\end{array}$ & $\begin{array}{l}\text { Dalimu } \\
\text { nthe } \\
(2010)\end{array}$ \\
\hline 3. & $\begin{array}{l}\text { Excellent } \\
\text { Service }\end{array}$ & $\begin{array}{l}\text { - Prosedur } \\
\text { Pelayanan } \\
\text { - Persyaratan } \\
\text { Pelayanan } \\
\text { - Kecepatan } \\
\text { Pelayanan } \\
\text { - Kepastian } \\
\text { Jadwal } \\
\text { Pelayanan } \\
\text { - Keadilan } \\
\text { Mendapat } \\
\text { Pelayanan } \\
\text { - Kewajaran } \\
\text { Biaya } \\
\text { Pelayanan } \\
\text { - Kepastian } \\
\text { Biaya } \\
\text { Pelayanan } \\
\text { - Kejelasan } \\
\text { Petugas } \\
\text { Layanan } \\
\text { - Kedisiplinan } \\
\text { Petugas } \\
\text { Layanan } \\
\text { - Tanggung } \\
\text { Jawab Petugas } \\
\text { - Kemampuan } \\
\text { Petugas } \\
\text { - Kesopanan dan } \\
\text { Keramahan } \\
\text { Petugas }\end{array}$ & $\begin{array}{l}\text { Kep } \\
\text { Men } \\
\text { Pan No. } \\
\text { KEP/25 } \\
\text { /M.PA } \\
\text { N/2/20 } \\
04\end{array}$ \\
\hline
\end{tabular}




\begin{tabular}{|c|c|c|c|}
\hline No & Variabel & Indikator & Sumber \\
\hline & & $\begin{array}{l}\text { - Kenyamanan } \\
\text { Lingkungan } \\
\text { - Keamanan } \\
\text { Pelayanan }\end{array}$ & \\
\hline 4. & Trust & $\begin{array}{l}\text { - Ability } \\
\text { - Benevolence } \\
\text { - Integritas }\end{array}$ & $\begin{array}{l}\text { Mayers } \\
\text { dalam } \\
\text { Restika } \\
(2012)\end{array}$ \\
\hline
\end{tabular}

\section{Analisis Kualitatif}

Metode yang digunakan adalah pendekatan existential phenomenology. Metode pengumpulan data yang digunakan yaitu dengan interview, observasi dan dokumentasi (Chariri, 2009)

\section{Informan dan Pengumpulan Informasi}

Informan dipilih berdasarkan kriteria dari Bungin (2003), bahwa informan merupakan individu yang telah cukup lama dan intensif menyatu dengan kegiatan atau medan aktivitas yang menjadi sasaran penelitian. Pengumpulan informasi dilakukan melalui wawancara dan diskusi yang tidak terstruktur, dan tidak terjadwal. Tabel 2 di bawah menunjukkan informan yang terpilih

Tabel 2 Informan Penelitian

\begin{tabular}{|l|l|l|}
\hline $\begin{array}{c}\text { Identitas } \\
\text { Informan }\end{array}$ & $\begin{array}{c}\text { Lama } \\
\text { Bekerja }\end{array}$ & \multicolumn{1}{|c|}{ Posisi } \\
\hline Nining & 18 tahun & $\begin{array}{l}\text { Staff Bidang Perdagangan } \\
\text { Luar Negeri }\end{array}$ \\
\hline Supri & 6 tahun & $\begin{array}{l}\text { Staff Bidang Perdagangan } \\
\text { Luar Negeri }\end{array}$ \\
\hline Heru & 25 tahun & $\begin{array}{l}\text { Staff Bidang Perdagangan } \\
\text { Luar Negeri }\end{array}$ \\
\hline Budi & 20 tahun & $\begin{array}{l}\text { Staff Bidang Perdagangan } \\
\text { Luar Negeri }\end{array}$ \\
\hline Sartono & $\begin{array}{l}\text { Staff Bidang Perdagangan } \\
\text { DalamNegeri }\end{array}$ \\
\hline Cahyo & 6 tahun & $\begin{array}{l}\text { Staff Perdagangan Dalam } \\
\text { Negeri }\end{array}$ \\
\hline Sinta & $\begin{array}{l}\text { Staff Perlindungan } \\
\text { Konsumen dan } \\
\text { Pengawasan Barang } \\
\text { Beredar }\end{array}$ \\
\hline Mahmud & 11 tahun & $\begin{array}{l}\text { Staff Perlindungan } \\
\text { Konsumen dan } \\
\text { Pengawasan Barang } \\
\text { Beredar }\end{array}$ \\
\hline
\end{tabular}

Catatan: Nama-nama informan adalah bukan nama sebenarnya

\section{HASIL DAN PEMBAHASAN}

\section{Analisis Structural Equation Modeling \\ Hasil Uji Kelayakan Model (Model Fit)}

Tabel 3. General SEM Analysis Result

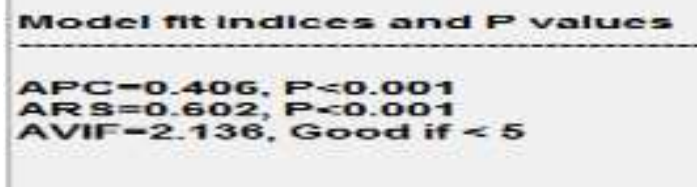

Hasil output general result di atas menunjukkan model mempunyai fit yang baik, dimana nilai P-value untuk APC dan ARS $<0.001$. Begitu juga dengan nilai AVIF yang dihasilkan yaitu $<3.3$, yang berarti bahwa tidak ada masalah multikolinearitas antar indikator dan antar variabel eksogen.

\section{Analisis Model Pengukuran}

Tabel 4 Loading Factor

\begin{tabular}{|c|c|c|c|c|c|c|c|c|c|}
\hline \multicolumn{2}{|c|}{ ID } & \multicolumn{2}{|c|}{ GG } & \multicolumn{4}{|c|}{ KP } & \multicolumn{2}{|c|}{ TRUST } \\
\hline$x_{1}$ & 0,82 & $\times 9$ & 0,72 & $Y_{1}$ & 0,77 & $\mathrm{Y} 10$ & 0,84 & Y15 & 0,92 \\
\hline$x z$ & 0,83 & $\mathrm{X} 10$ & 0,83 & $Y_{2}$ & 0,74 & Y11 & 0,85 & Y16 & 0,95 \\
\hline$\times 3$ & 0,75 & $\mathrm{x} 11$ & 0,88 & $Y_{3}$ & 0,79 & $\mathrm{Y} 12$ & 0,79 & Y17 & 0,94 \\
\hline$x A$ & 0,84 & $\mathrm{x} 12$ & 0,86 & Y4 & 0,75 & $\mathrm{Y} 13$ & 0,78 & & \\
\hline XS & 0,89 & $\mathbf{x 1 3}$ & 0,90 & YS & 0,80 & $\mathrm{Y} 14$ & 0,80 & & \\
\hline$\times 6$ & 0,92 & $\mathrm{x} 14$ & 0,88 & Y6 & 0,61 & & & & \\
\hline$x 7$ & 0,85 & $\mathrm{x} 15$ & 0,76 & $r$ & 0,58 & & & & \\
\hline$\times 8$ & 0,86 & $\mathrm{x} 16$ & 0,87 & Y8 & 0,83 & & & & \\
\hline & & x17 & 0,72 & Y 9 & 0,81 & & & & \\
\hline
\end{tabular}

Tabel $4 \mathrm{di}$ atas menunjukkan bahwa hampir seluruh indikator pembentuk konstruk laten memiliki nilai loading factor $>0.5$ yang berarti bahwa indikator tersebut telah memenuhi kriteria indicator reliability (Ghozali, 2014)

\section{Tabel 5. Latent Variabel Coefficient}

\begin{tabular}{|c|c|c|c|c|}
\hline & 10 & GG & KP & TRUST \\
\hline A-squared & & 0.440 & 0.800 & 0.765 \\
\hline Composte retiab. & 0.953 & D. 950 & 0.953 & 0.956 \\
\hline Counteresis alptis & 0.943 & 0.940 & 0.947 & 0.931 \\
\hline Avg var, otrac: & 0.717 & 0.681 & 0.596 & 0.879 \\
\hline Full collin ve & \multirow[t]{2}{*}{1.927} & 3911 & 2756 & 4.170 \\
\hline O-squered & & 0.438 & 0,000 & 0.767 \\
\hline
\end{tabular}

Dari tabel 5 latent variable coefficient terlihat bahwa nilai composite reliability untuk semua variabel di atas 0.7 begitu juga dengan nilai cronbach alpha semua juga di atas 0.7 sehingga memenuhi reliabilitas konsistensi internal. Nilai AVE untuk semua variabel sangat baik $(>0.5)$ sehingga memenuhi validitas konvergen. Nilai full 
colliniearity VIF juga baik yaitu $<5$, tidak terdapat problem collinearity dalam model. Nilai $Q$ Squared untuk setiap variabel endogen $>0$ yang berarti bahwa model mempunyai predictive relevance.

\section{Analisis Model Struktural}

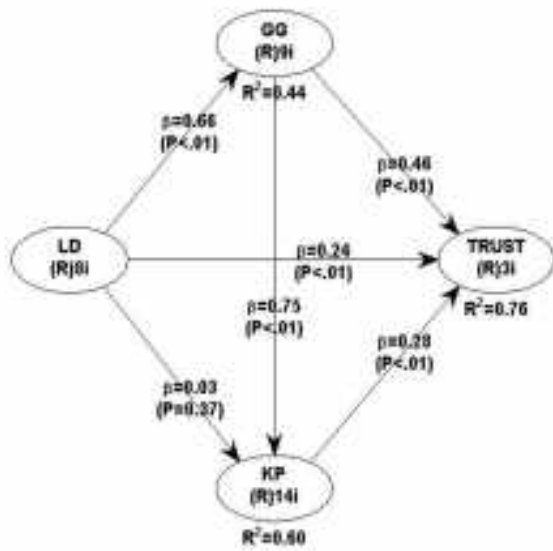

Gambar 2

\section{Hasil Analisis Model Struktural}

Berdasarkan gambar 10. di atas diperoleh hasil sebagai berikut:

1. Gaya Kepemimpinan Transformasional (LD) berpengaruh positif signifikan terhadap implementasi Good Governance (GG)

2. Gaya Kepemimpinan Transformasional (LD) tidak berpengaruh terhadap Excellent service (KP)

3. Gaya Kepemimpinan Transformasional (LD) berpengaruh positif signifikan terhadap Kepercayaan Masyarakat (Trust)

4. Implementasi Good Governance (GG) berpengaruh positif signifikan terhadap Excellent Service (KP)

5. Implementasi Good Governance (GG) berpengaruh positif signifikan terhadap Kepercayaan Masyarakat (Trust)

6. Excellent (KP) berpengaruh positif signifikan terhadap Kepercayaan Masyarakat (Trust)

Koefisien $R$-Square untuk Good Governance sebesar 0.44 yang berarti bahwa variasi dari implementasi good governance dapat dijelaskan oleh Gaya Kepemimpinan Transformasional sebesar $44 \%$. Koefisien $R$-Square untuk Kinerja Pelayanan sebesar 0.60 yang berarti bahwa implementasi good governance dan gaya kepemimpinan transformasional mampu menjelaskan variasi dari kinerja pelayanan sebesar $60 \%$. Selanjutnya $R$-Square untuk kepercayaan masyarakat sebesar 0.76 yang berarti bahwa gaya kepemimpinan transformasional, good governance dan kinerja pemasaran mampu menjelaskan variasi dari kepercayaan masyarakat sebesar $76 \%$.

\section{Indirect Effect}

Tabel 6. Output Pengujian Indirect Effect

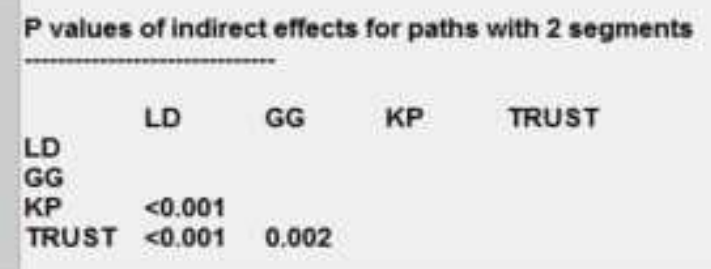

a. Pengaruh tidak langsung Gaya Kepemimpinan terdahap Kepercayaan Masyarakat

Kepemimpinan Transformasional $\rightarrow$ Good Governance $\rightarrow$ Trust

Hasil output indirect effect untuk good governance signifikan pada $0.002<0.05$ yang berarti bahwa Good Governance dapat menjadi variabel mediator secara parsial (partial mediation) untuk hubungan kepemimpinan transformasional dan kepercayaan. Kepemimpinan transformasional dapat secara langsung mempengaruhi kepercayaan, atau secara tidak langsung mempengaruhi kepercayaan dengan melalui good governance.

Kepemimpinan Transformasional $\rightarrow$ Excellent Service $\rightarrow$ Trust

Hasil output indirect effect untuk good governance signifikan pada taraf $<0.001$, hal ini berarti bahwa excellent service tidak dapat menjadi variabel mediator (no mediation) untuk hubungan kepemimpinan transformasional dan kepercayaan. Kepemimpinan transformasional dapat secara langsung mempengaruhi kepercayaan tanpa melalui excellent service.

b. Pengaruh tidak langsung Kepemimpinan Transformasional terhadap Excellent service Kepemimpinan Transformasional $\rightarrow$ Good Governance $\rightarrow$ Excellent Service

Hasil output indirect effect untuk good governance signifikan pada $0.002<0.05$ hal ini berarti bahwa Good Governance dapat menjadi variabel mediator secara penuh (full mediation) untuk hubungan kepemimpinan transformasional dan excellent service. Kepemimpinan transformasional harus mampu terlebih dahulu menjalankan good governance untuk dapat meningkatkan kinerja pelayanan (excellent service).

c. Pengaruh tidak langsung Good Governance terhadap Kepercayaan Masyarakat 
Good Governance $\rightarrow$ Excellent Service $\rightarrow$ Trust

Hasil output indirect effect untuk excellent service signifikan pada taraf $<0.001$ yang berarti bahwa excellent service dapat menjadi variabel mediator secara parsial (partial mediation) untuk hubungan good governance dan trust. Good governance dapat secara langsung mempengaruhi trust, atau secara tidak langsung mempengaruhi trust dengan melalui excellent service.

\section{Pembahasan}

\section{Gaya Kepemimpinan Transformasional berpengaruh positif signifikan terhadap implementasi Good Governance}

Hasil penelitian menunjukkan semakin baik gaya kepemimpinan transformasional yang dijalankan, semakin baik pula implementasi dari good governance. Good governance adalah sebuah kebijakan yang dilaksanakan oleh suatu organisasi untuk mencapai kinerja yang lebih baik sedangkan kepemimpinan transformasional dapat menghasilkan dan melaksanakan kebijakan publik yang lebih efektif (zulkifli, 2013). Menurut Hayat (2014) kepemimpinan transformasional mampu membuat pegawai mengaktualisasikan diri dalam penerapan kebijakan secara realistis yang berorientasi kepada good governance. Selanjutnya hayat menjelaskan bahwa kepemimpinan menjadi tonggak keberhasilan dari reformasi birokrasi dalam pelayanan publik terhadap tujuan good governance. Hasil ini mendukung penelitian yang dilakukan oleh Lestari (2012).

Setelah dilantik menjadi Kadinas Perindag Prov Jateng, Prijo Anggoro BR, SH, MSi menyampaikan pengarahan pada apel pagi bahwa: "seluruh jajaran PNS dapat meningkatkan produktivitas kerja, menjaga kebersamaan, menjalankan kegiatan sesuai rencana kerja serta mengedepankan kejujuran terutama dalam pelayanan masyarakat" (03 Februari 2015)

Dari kutipan tersebut terlihat bahwa pemimpin memiliki komitmen untuk melaksanakan prinsipprinsip good governance seperti partisipasi, transparasi, dan akuntabilitas dalam setiap kegiatan kerja yang dilakukan di lingkungan Dinperindag. Untuk itu gaya kepemimpinannya akan berpengaruh terhadap implementasi good governance di lingkup Dinperindag.

Nining karyawan Dinperindag Jateng yang telah bekerja selama 18 tahun mengatakan bahwa: "Bapak selalu mengingatkan, kalau bekerja harus selalu menggunakan hati nurani, sesuai dengan etika dan nilai-nilai yang berlaku, terlebih kita bekerja sebagai pelayan masyarakat dan beliau selalu mendukung kreatifitas bawahanya asal tetap sesuai dengan aturan yang berlaku" (15 Juni 2015)
Dari kutipan wawancara tersebut terlihat bahwa pemimpin menerapkan aspek akuntabilitas dalam bekerja. Jadi sebagai manusia kita harus menggunakan hati nurani dan semua pekerjaan itu tidak hanya dipertanggung jawabkan kepada pimpinan, namun juga pada Tuhan yang Maha Esa.

Supri, Staff Dinperindag yang telah bekerja selama 6 tahun mengatakan bahwa:

"Pak Priyo menjadi cerminan bapak yang bijak yang dapat mengayomi anak buahnya, tidak membeda-bedakan anak buah dan berlaku adil terhadap semua karyawan" (15 Mei 2015)

Dari kutipan wawancara tersebut di atas prinsip equity telah dilaksanakan dalam kepemimpinan di Dinperindag. Dengan tidak membeda-bedakan bawahan, bawahan akan merasa dihargai dan merasa aman, hal tersebut akan mendorong bawahan untuk melakukan hal yang sama yang ditunjukkan oleh pemimpin dalam memberikan pelayanan kepada masyarakat.

Gaya Kepemimpinan Transformasional tidak berpengaruh terhadap Excellent Service

Hasil menunjukkan kepemimpinan bahwa baik buruknya kinerja pelayanan di Dinperindag tidak dipengaruhi oleh gaya kepemimpinan yang dijalankan. Hasil ini mendukung penelitian Setiawan (2015) dan Lomanja (2013). Heru staff Dinperindag dengan mengatakan bahwa

"Setiap bagian di Dinperindag memiliki SOP (standar operational procedure) dalam menjalankan tugasnya, SOP menjadi landasan dasar setiap karyawan dalam bertindak (15 Juni 2015)"

Budi Staff Dinperindag yang sudah bekerja selama 8 tahun mengatakan bahwa:

"Dinperindag punya tupoksi yang jelas dan mengarah untuk masyarakat dan seluruh pegawai bekerja sesuai dengan tupoksi masing-masing, selain itu Dinperindag juga memiliki sistem prosedur kerja yang jelas"

Berdasarkan kutipan hasil wawancara tersebut mengandung arti bahwa, setiap anggota organisasi dapat bekerja secara mandiri berdasarkan SOP ataupun Tupoksi yang telah ada. SOP dan Tupoksi menjadi pedoman karyawan dalam bertindak dan dengan adanya SOP dan tupoksi perusahaan dapat memastikan suatu aktivitas pelayanan bisa berjalan sesuai dengan standar yang diharapkan. Hal ini dapat menjadi alasan kenapa gaya kepeminpinan tidak berpengaruh terhadap kinerja pelayanan.

$$
\text { Selain itu berdasarkan observasi, }
$$
Kepemimpinan Kepala Dinperindag belum genap 1 (satu) tahun, Prijo Anggoro Budi Rahardjo, SH, MSi diangkat menjadi Kepala Dinas Perindustrian dan Perdagangan Jawa Tengah pada tanggal 30 Januari 2015 yang sebelumnya menjabat sebagai Sekretaris DPRD Jateng. Masa kepemimpinan 
yang pendek tersebut belum memperlihatkan dampak yang signifikan terhadap kinerja perusahaan.

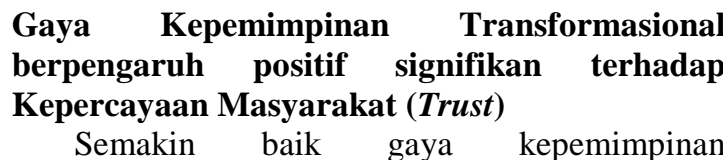
transformasional yang dijalankan, semakin meningkat pula kepercayaan masyarakat terhadap Dinperindag. Menurut Zulkifli (2013) kepercayaan publik sangat berhubungan dengan kepemimpinan etis dan transformasional. Sanapiah (2007) menjelaskan bahwa peran pemimpin dalam membangun kepercayaan publik mencakup lingkup internal yang berkaitan dengan upaya menggerakkan dan memastikan seluruh sumberdaya aparatur berkinerja tinggi, dan lingkup eksternal organisasi dalam upaya mencermati harapan masyarakat dan komunikasi eksternal baik menyangkut ukuran-ukuran kinerja pelayanan (public service measures) yang ditetapkan, upaya yang telah, sedang dan akan dilakukan, maupun kinerja pelayanan yang telah dihasilkan.

Kebajikan atau harapan bahwa orang yang dipercaya akan berperilaku positif terhadap orangorang yang memercayai kebajikan menunjukkan goodwill dan sisi baik pada bagian pengenalan dari orang-orang yang diamanatkan menjadi pemimpin, terhadap orang yang memercayai atau pemilih. Hasil ini mendukung penelitian yang dilakukan oleh Yulianti (2015), Saputra (2013), dan Yogi (2011)

Kepemimpinan transformasional memberikan contoh dan role model yang positif dalam perilaku sikap, prestasi, maupun komitmen terhadap anggota atau pengikutnya. Keadaan ini tercermin dalam standar moral dan etis yang tinggi. Ia sangat memperhatikan kebutuhan anggotanya khususnya masyarakat. Hal ini terlihat dari tindakan yang diambil oleh pemimpin Dinperindag sebagai wujud perhatiannya terhadap kebutuhan masyarakat yaitu pada tanggal 09 Februari sampai tanggal 17 Maret 2015 telah dilaksanakan program pelatihan keterampilan SDM industri di bidang garmen siap kerja. Pelatihan yang diikuti oleh 220 peserta dilaksanakan karena mengingat kebutuhan SDM industri garmen siap kerja semakin bertambah seiring dengan meningkatnya ekspor Tekstil dan Produk Tekstil (TPT) akibat pembatasan masuknya TPT China ke pasar Amerika, Eropa dan beberapa pasar non tradisional.
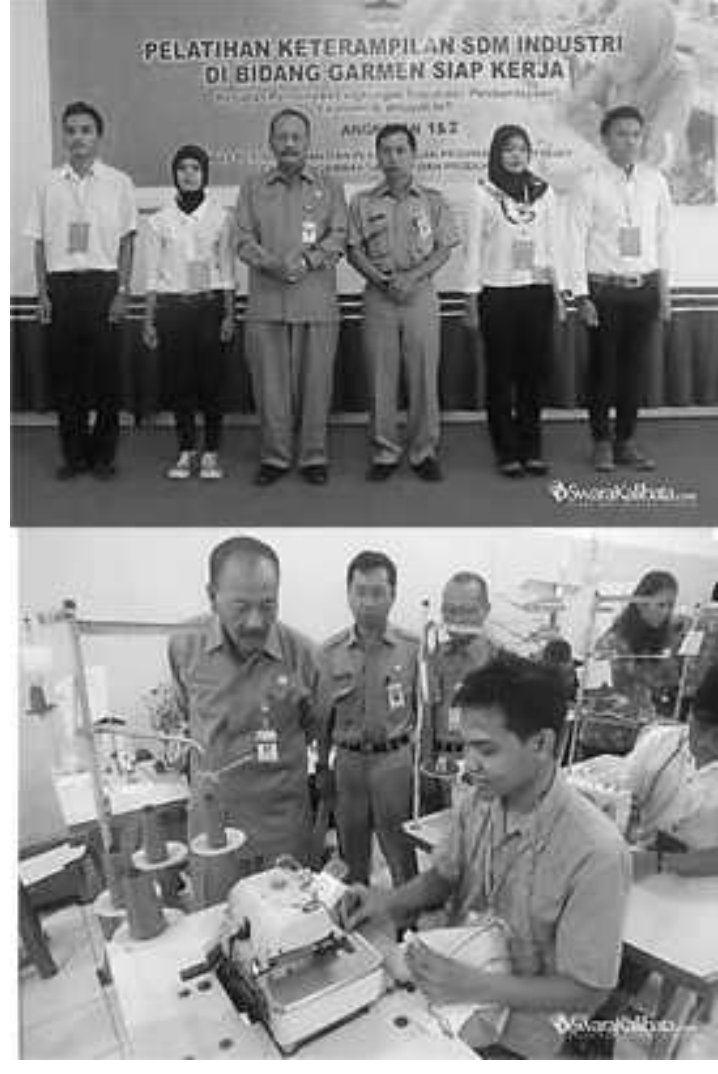

\section{Gambar 3. \\ Pelatihan Keterampilan SDM Industri di Bidang Garmen Siap Kerja}

Pelatihan keterampilan SDM industri di Bidang Garmen siap kerja yang diselenggarakan oleh Pemerintah Provinsi Jawa Tengah merupakan wujud nyata bentuk fasilitasi kepada masyarakat sehingga mampu menumbuhkan kepercayaan masyarakat terhadap Dinperindag. Selain itu banyak kegiatan-kegiatan yang dilakukan oleh Dinperindag dibawah kepemimpinan prijo Anggoro Budi Rahardjo, SH, MSi yang berorientasi kepada kebutuhan masyarakat, seperti "Pelatihan Achivement sebagai Upaya Membentuk Mental Baja" (24 Maret-9 April 2015), kegiatan "Temu Usaha UMKM untuk Tingkatkan Jaringan Pasar" (17-18 Maret 2015), dsb. Melalui perilaku atau tindakan yang memperhatikan kebutuhan para pengikutnya, maka pengikut atau anggota masyarakat akan menaruh respek, rasa kagum, dan percaya kepada pimpinannya.

Selanjutnya, Sartono, Staff yang telah 20 tahun bekerja mengatakan bahwa:

"berkat kepemimpinan sekarang ini, sering diadakan acara-acara seperti pameran-pameran yang berdaya saing tinggi dan berkualitas untuk baik itu masyarakat umum maupun untuk pelaku industri" (15 Mei 2015) 
Supri salah satu Staff Diperindag yang telah bekerja selama 6 tahun mengatakan bahwa:

"bapak itu cepat responsif untuk mengatasi keluhan masyarakat dan segera mungkin ditindak lanjuti jadi keluhan-keluhan masyarakat tidak hanya ditampung namun segera ditidak lanjuti" (15 Mei 2015)

Menurut Nawawi (2007), sesuai dengan asas responsif, maka setiap unsur pemerintah akan memiliki etik yakni etik individual menuntut mereka agar memiliki kriteria kapabilitas dan loyalitas profesional. Sedang etik sosial menuntut mereka agar memiliki sentifitas terhadap berbagai kebutuhan publik. Kedua etik apabila diaplikasikan demi kepentingan publik maka akan terbangun kepercayaan.

\section{Implementasi Good Governance berpengaruh positif signifikan terhadap Excellent Service}

Dari hasil penelitian diketahui bahwa semakin baik implementasi good governance, semakin baik pula kinerja pelayanan yang dihasilkan. Hal ini sejalan dengan pernyataan Surya yang dikutip oleh Dalimunte (2010) yang menjelaskan bahwa mutu dan kualitas pelayanan menjadi lebih baik dan memuaskan dan tidak menimbulkan keluhan masyarakat dalam menerima pelayanan setelah adanya penerapan prinsip-prinsip good governance. Paradigma good governance menjadi relevan dan menjiwai kebijakan pelayanan publik di era otonomi daerah yang diarahkan untuk meningkatkan kinerja manajemen pemerintahan, mengubah sikap mental, perilaku aparat penyelenggara pelayanan serta membangun kepedulian dan komitmen pimpinan daerah dan aparatnya untuk memperbaiki dan meningkatkan pelayanan publik yang berkualitas (Ahmad, 2009). Menurut Barus (2011) pengaruh pelaksanaan good governance sangat tinggi terhadap pelayanan publik. Hasil ini mendukung penelitian yang dilakukan oleh Ferlianda (2012), Lestari (2012) dan Barus (2011)

Pengaruh pelaksanaan prinsip-prinsip good governance terhadap excellent service di Dinperindag Jateng terlihat dari masuknya Dinperindag Jateng dalam 3 besar SKPD Pemeringkatan Komisi Informasi tahun 2014. Komisi informasi merupakan lembaga mandiri yang berfungsi menjalankan Undang-Undang Keterbukaan Informasi Publik dan peraturan pelaksanaannya termasuk menetapkan petunjuk teknis standar layanan Informasi Publik dan menyelesaikan Sengketa Informasi Publik melalui Mediasi dan ajudikasi nonlitigasi. Masuknya Dinperindag Jateng dalam 3 besar peringkat komisi informasi menunjukkan bahwa Dinperindag telah mengimplementasikan prinsipprinpsip good governance dengan baik.
Transparansi adalah kunci dari pemerintahan yang bersih. Pemeringkatan Badan Publik oleh komisi informasi di dasarkan pada UU No. 14 Tahun 2008 tentang Keterbukaan Informasi, dan dasar hukum yang lain seperti Peraturan Komisi Informasi No. 1 Tahun 2010 tentang Standar Pelayanan Informasi Publik, Permendagri No. 35 Tahun 2010 tentang Pedoman Pengelolaan Pelayanan dan Dokumentasi di Lingkungan Kementerian Dalam Negeri, Peraturan Daerah No. 6 Tahun 2012 tentang Pelayanan Informasi Publik Penyelenggaraan Pemerintah Daerah Provinsi Jawa Tengah dan sebagainya. Jadi dapat disimpulkan bahwa Dinperindag telah melaksanakan prinsip akuntabilita yaitu mengikuti peraturan perundangundangan dan dasar hukum lainnya sehingga mampu menciptakan exccellent service yang di buktikan dengan masuknya Dinperindag dalam 3 besar Pemeringkatan Badan Publik oleh komisi informasi.

Cahyo, Staff Dinperindag yang telah bekerja selama 30 tahun mengatakan bahwa:

"Disini semua informasi yang berkaitan dengan pelayanan selalu terbuka, kami telah melaksanakan tugas sesuai dengan anjuran pemerintah untuk meningkatkan kinerja layanan dan memang selalu ada keterlibatan msayarakat dn pemerintah dalam perbaikan layanan" (15 Mei 2015)

Sinta, Staff Dinperindag yang telah bekerja selama 6 tahun mengatakan bahwa

"Dinperindag bertugas di bidang perindustrian dan perdagangan oleh karena itu orientasinya sebagain besar pada kebutuhan masyarkat, dan masyarakt dapat berpartisipasi dalam perbaikan kualitas layanan dengan mudah, misalnya melalui kotak saran, mengirim email, dsb” (15 Mei 2015)

Mahmud, Staff Dinperindag yang telah bekerja selama 11 tahun menambahkan:

"kami disini bekerja sesuai dengan undangundang, karyawan Dinperindag dalam bekerja ditanamkan untuk tidak melanggar aturan-aturan yang telah disepakati jadi Insyaallah tidak ada yang mengambil hak masyarakat ataupun korupsi di Dinperindag” (15 Mei 2015)

Dari kutipan wawancara di atas tersirat bahwa prinsip-prinsip dari good governance telah dilaksanakan oleh karyawan Dinperindag dan karyawanpun telah menyadari bahwa orientasi terbesar mereka dalam bekerja adalah untuk kepentingan masyarakat

\section{Implementasi Good Governance (GG) berpengaruh positif signifikan terhadap Kepercayaan Masyarakat (Trust)}

Implementasi good governance yang semakin baik dapat meningkatakan kepercayaan masyarakat terhadap Dinperindag. Menurut Nurcahyani 
(2012), penerapan prinsip good governance secara konsisten dan berkesinambungan dapat menghasilkan kepercayaan publik. Budi Santoso, anggota Ombudsman RI (2014) mengatakan diperlukan integritas, akuntabilitas, dan transparansi sebagai pendorong peningkatan kepercayaan terhadap publik.Hasil ini mendukung penelitian Alif (2013), Junusi (2005) dan Islamey (2014).

Berikut adalah bukti-bukti dari implementasi good governance oleh Dinperindag Jateng sebagai upaya meningkatkan kepercayaan masyarakat, antara lain kutipan Wawancara dari Mahmud selaku staff bagian pelayanan yang telah 11 tahun bekerja di Dinperindag, mengatakan bahwa:

"untuk mengetahui informasi lebih dalam masyarakat dapat membuat surat untuk menanyakan semua hal-hal yang berhubungan dengan pelayanan, selain itu semua informasi terkait pelayanan di pasang di papan pengumuman dan website, semua diinformasikan secara terbuka” (15 Mei 2015)

Gambar di bawah menunjukkan aplikasi website dan sosial media yang mencerminkan pelaksanaan prinsip good governance oleh Dinperindag dan sekaligus sebagai sarana untuk mendekatkan diri kepada masyarakat untuk membangun kepercayaan masyarakat
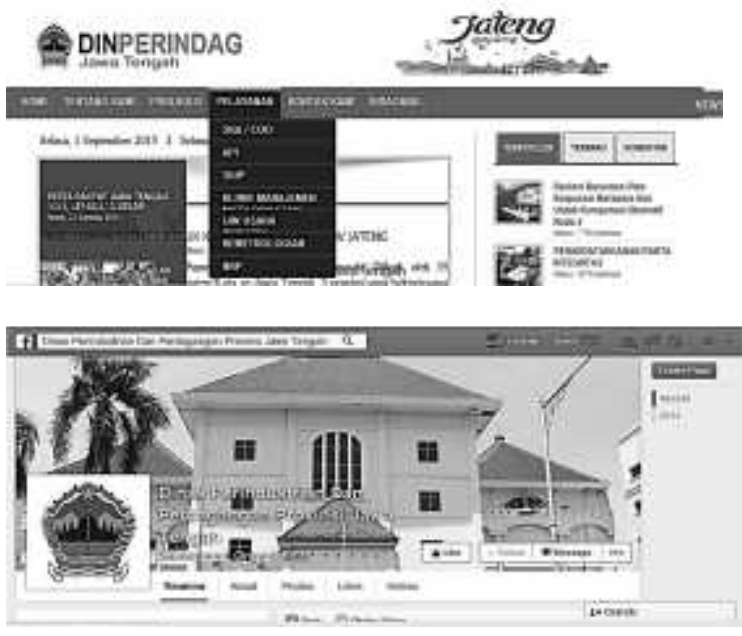

Gambar 4.

Website dan Facebook Dinperindag Jateng

Selain itu dalam menyusun kebijakan Dinperindag juga melibatkan partisipasi dari para stakeholder seperti yang telah dilakukan yaitu menggelar Forum Komunikasi Peningkatan Ekspor Jawa Tengah yang dilaksanakan pada tanggal 12 Januari 2015, tujuan kegiatan ini adalah untuk mensosialisasikan "Strategi Melipat-tigakan Ekspor dalam lima Tahun Kedepan" dan mendapatkan masukan dari para akedemisi, praktisi, maupun stakeholders terkait mengenai isu-isu strategis serta input yang diperlukan dalam penyusunan strategi tersebut. Kebijakan yang melibatkan masyarakat akan lebih dipercaya dan dilaksanakan dengan sepenuh hati.

\section{Excellent Service berpengaruh positif signifikan terhadap Kepercayaan Masyarakat (Trust) \\ Kinerja pelayanan yang semakin baik akan} meningkatkan kepercayaan terhadap masyarakat. Kepercayaan publik tumbuh dari pelayanan yang berkualitas. Hal tersebut sejalan dengan pernyataan OECD (2000) bahwa pada dasarnya pelayanan publik adalah kepercayaan publik. Menurut Sanapiah (2007) kualitas pelayanan publik merupakan salah satu strategic issue bagi aparatur negara yang harus diaktualisasikan dalam kerangka membangun kepercayaan publik. Garbarino dan Jhonson dalam Jahroni (2009), menyatakan bahwa kepercayaan sebagai keyakinan konsumen akan kualitas dan keandalan pelayanan yang ditawarkan oleh suatu organisasi. Kepercayaan masyarakat akan tumbuh jika suatu organisasi memberikan kepastian, meningkatkan kualitas, dan kinerja pelayanan sesuai dengan kebutuhan masyarakat dan selaras dengan kemampuan penyelenggara layanan (Brawijaya, 2013). Hasil ini mendukung penelitian Cahyani (2014), Rini (2014), dan Kurniawan (2012).

Pada tahun 2013 Dinperindag Jateng telah meraih penghargaan daerah peduli konsumen yang diselenggarakan di Swiss Belhotel, Jakarta.

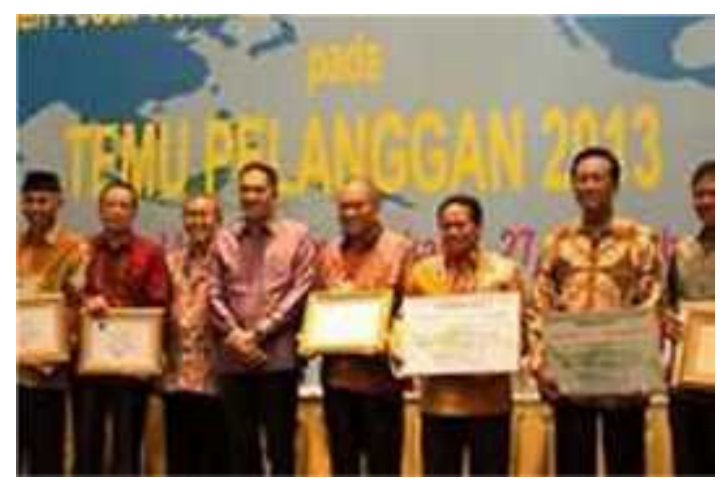

Gambar 5

\section{Penghargaan Daerah Peduli Konsumen}

Penghargaan daerah peduli konsumen menunjukkan bahwa Dinperindag jateng selalu melakukan pembinaan dan perlindungan terhadap konsumen dalam hal ini adalah masyarakat. Excellent Service Dinperindag yang dibuktikan dengan penghargaan yang diterimanya meningkatkan hubungan kerjasama yang lebih baik dengan masyarakat sehingga membawa umpan balik yaitu kepercayaan masyarakat terhadap instansi tersebut. 


\section{SIMPULAN}

\section{Implikasi Teoritis}

1) Prinsip good governance dapat meningkatkan kinerja pelayanan dan kepercayaan publik, serta gaya kepemimpinan transformasional dapat meningkatkan kepercayaan publik

2) Gaya kepemimpinan transformasional tidak mempengaruhi kinerja pelayanan hal ini dapat disebabkan oleh SOP dan Tupoksi yang menjadi pedoman karyawan dalam bertindak untuk menghasilkan kinerja yang baik. Selain itu masa kepemimpinan yang pendek belum dapat membuktikan dampak dari gaya kepemimpinan yang digunakan terhadap kinerja pelayanan yang dihasilkan

\section{Implikasi Manajerial}

Saran yang dapat diberikan dalam penelitian ini untuk Dinperindag Jatrng adalah:

a. Untuk terus meningkatkan gaya kepemimpinan transformasional, karena gaya kepemimpinan ini dapat meningkatkan implementasi good governance yang pada nantinya membawa kepercayaan terhadap masyarakat

b. Untuk terus mengaplikasikan pinsip-prinsip good governance dalam setiap aktivitas bisnis, karena prinsip ini dapat membawa kinerja pelayanan yang terbaik dan membangun kepercayaan masyarakat terhadap organisasi publik

\section{Keterbatasan Penelitian}

a. Pengumpulan data penelitian hanya dilakukan di kantor Dinperindag Jateng, yaitu dengan membagi kuesioner kepada responden yang sedang mengurus perijinan di Dinperindag serta sampling yang digunakan adalah metode quota sampling. Sehingga mayoritas responden berdomisili di wilayah Semarang dan sekitarnya dan tidak mewakili seluruh daerah di Jawa Tengah

b. Hasil penelitian tidak bisa digeneralisir di luar wilayah atau obyek penelitian

\section{Agenda Penelitian Mendatang}

1) Penelitian selanjutnya dapat meliput wilayah lain yang lebih luas untuk dapat mengeneralisir hasil.

2) Untuk mendapatkan hasil penelitian yang lebih umum maka perlu dilakukan penelitian lebih lanjut dengan unit analisis pada beberapa perusahan/instansi.

\section{DAFTAR PUSTAKA}

Alif, Nurohmah, "Analisis Pengaruh PrinsipPrinsip Good Corporate Governance (GCG) terhadap Kepercayaan Nasabah pada Bank Muamalat Kendal”. Undergraduate (S1) thesis, IAIN Walisongo, 2013.

Antarwiyati, Prapti, dkk, "Determinan Electronic Loyalty (E-Loyalty) pada Website", Fakultas Ekonomi, Universitas Islam Indonesia, 2006

Arisman, "Peran Kepemimpinan Dalam Membangun Kepercayaan Masyarakat Terhadap Pelayanan Publik", Makalah Kepemimpinan, 2014

Brawijaya, "Pelayanan Prima Unit Pelayanan Publik", PJM Universitas Brawijaya, 2013

Bungin, B, “Analisis Data Penelitian Kualitatif: Pemahaman Filosofis dan Metodologis ke Arah Penguasaan Model Aplikasi”. Cetakan Pertama. Jakarta: Raja Grafindo Persada, 2003

Cahyani, Komang Indah Gita, Gede Bayu Rahanatha, "Pengaruh Kualitas Layanan terhadap Kepuasan dan Dampaknya pada Kepercayaan serta Loyalitas", Fakultas Ekonomi dan Bisnis Universitas Udayana (Unud), Bali, Indonesia, 2014

Dalimunthe, RF, “Analisis persepsi karyawan bagian administrasi umum tentang penerapan prinsip Good Corporate Governance (transparansi, akuntabilitas, keadilan, dan partisipasi) kaitannya dengan kinerja karyawan di Rumah sakit Umum Daerah dr. Zainoel Abidin Banda Aceh tahun 2009" Universitas Sumatera Utara, 2010

Firdayanti, Restika, "Persepsi Risiko Melakukan E-Commerce dengan Kepercayaan Konsumen dalam Membeli Produk Fashion Online", Journal of Social and Industrial Psychology, Universitas Negeri Semarang, 2012

Chariri, A. "Landasan Filsafat dan Metode Penelitian Kualitatif", Paper disajikan pada Workshop Metodologi Penelitian Kuantitatif dan Kualitatif, Laboratorium Pengembangan Akuntansi (LPA), Fakultas Ekonomi Universitas Diponegoro Semarang, 2009 
Ghozali, Imam, "Structural Equation Modeling: Teori, Konsep, dan Aplikasi dengan Program Lisrel 8.80”, edisi dua, BP UNDIP, Semarang 2008

Ghozali, Imam, Hengky Latan, "Partial Least Square, Konsep, Metode dan Aplikasi Menggunakan Program WrapPLS 4.0". second edition, Universitas Diponegoro Semarang, 2014

Hamka, "Kualitas Pelayanan Publik: Implikasi Reorganisasi Kelembagaan Pemerintah Kabupaten/Kota”, STIA LAN Jakarta

Hayat, "Konsep Kepemimpinan Dalam Reformasi Birokrasi:Aktualisasi Pemimpin Dalam Pelayanan Publik Menuju Good Governance", Jurnal Borneo Administrator, vol.10, no. 1,2014

Islamey, Yanuar Adinda, "Pengaruh pengendalian intern dan total quality management terhadap kepercayaan masyarakat pada badan dan lembaga amil zakat di jabodetabek dengan good governance sebagai variabel intervening", UIN Syarif Hidayatullah Jakarta : Fakultas Ekonomi dan Bisnis, Prodi Akuntansi, 2014

Jahroni, "Pengaruh Kualitas Layanan Terhadap Loyalitas Nasabah Melalui Kepuasan, Komitmen, Kepercayaan Pada Bank Central Asia Tbk", Jurnal Akuntansi, Manajemen Bisnis dan Sektor Publik (JAMBSP), Universitas Sunan Giri Surabaya, 2009

Junusi, Rahman El, "Implementasi Syariah Governance serta Implikasinya terhadap Reputasi dan Kepercayaan Bank Syariah”, Annual International Conference on Islamic Studies, 2005

Khoirusmadi, Ahhmad Shofian, "Analisis Pengaruh Kepemimpinan Transformasional terhadap Kinerja Pegawai dengan Budaya Organisasi sebagai Variabel Intervening (Studi pada Sekretariat Daerah Pemerintah Kota Pekalongan)", Universitas Diponegoro, 2011

Kushandajani, "Standar Pelayanan Minimal (SPM) dan Peningkatan Pelayanan Publik di Era Otonomi Daerah", 2005

Keputusan Menteri Pendayagunaan dan Aparatur Negara (MenPAN), “Asas Pelayanan
Publik dengan Prinsip-Prinsip Good Governance, Nomor 63/KEP/M.PAN/7/2003

Kurniawan, Wahyu, "Analisis Pengaruh Kualitas Pelayanan, Kualitas Produk dan Harga terhadap kepercayaan Konsumen Produk Notebook (Studi Kasus Terhadap Duamerknotebook)", Skripsi, Universitas Muhammadiyah Surakarta, 2014

Lestari, Vanny Sirnayati, "Pengaruh Gaya Kepemimpinan dan Penerapan Good Corporate Governance terhadap Kinerja Organisasi”, Jurusan Akuntansi, Fakultas Ekonomi, Universitas Siliwangi, 2012.

Lomanjaya, Jacqueline, Meliana Laudi, Deborah C. Widjaja, Endo Wijaya Kartika, "Analisis Pengaruh Gaya Kepemimpinan Transformasional dan Transaksional terhadap Kinerja Karyawan PT. ISS Indonesia Cabang Surabaya di Rumah Sakit Katolik St. Vincentius A. Paulo”, Manajemen Perhotelan, Fakultas Ekonomi, Universitas Kristen Petra, Surabaya, Indonesia, 2013

Mas'oed, Muchtar, “Tumbuhkan Kepercayaan Publik, Pemerintah Diminta Kedepankan Transparansi dan Akuntabilitas", Seminar Nasional, Fakultas Ilmu Sosial dan Ilmu Politik, Universitas Gajag Mada, Yogyakarta, 2004

Mansur, T, "Faktor-faktor yang Mempengaruhi Kualitas Pelayanan Publik pada Bagian Bina Sosial Setdako Lhokseumawe, Universitas Sumatera Utara, Medan, 2008

Marzal, "Ikhlas: Kunci Pelayanan Prima", Widyaiswara Muda BDK Palembang

Meilianasari, Yeni Dwi, "Analisis Kepercayaan Nasabah Pengguna ATM, Jurnal Manajemen Bisnis, Vol. 2, No. 0, Edisi April, Fakultas Ekonomi UMM, 2012

Nawawi, Juanda, "Membangun Kepercayaan dalam Mewujudkan Good Governance”, 2007

Rini, Elis Ayudianti Sekar, "Pengaruh Kualitas Pelayanan (Service Quality) terhadap Kepuasan dan Kepercayaan Konsumen dalam Memanfaatkan Jasa Lessing Pada PT. Bussan Auto Finance Cabang 
Pasuruan", Skripsi, Universitas Jember, 2014

Rofiq, Ainur, "Pengaruh Dimensi Kepercayaan (Trust) terhadap Partisipasi Pelanggan ECommerce (Studi Pada Pelanggan ECommerce Di Indonesia)", Fakultas Ekonomi Universitas Brawijaya, Malang, 2007

Rorimpandey, Lydia, “Gaya Kepemimpinan Transformasional, Transaksional, Situasional, Pelayanan Dan Autentik Terhadap Kinerja Pegawai Kelurahan Di Kecamatan Bunaken Kota Manado", Jurnal EMBA, Vol.1, No.4, 2013

Sanapiah, A.Aziz, "Dimensi Kepemimpinan Aparatur Publik dalam Perspektif Pelayanan Publik: Building Trust", Jurusan Administrasi Bisnis STIA LAN Jakarta, 2007

Sanusi, Anwar, "Metodelogi Penelitian Bisnis", Salemba Empat, 2014

Saputra, Beny Mahyudi, "Pengaruh Gaya Kepemimpinan Transformasional terhadap Kepuasan kerja melalui Kepercayaan Karyawan pada Atasan (Studi pada STT, STMIK, STBA dan Politeknik Cahaya Surya)", Jurnal OTONOMI, vol. 13, no.1, 2013

Setiawan, Eko Yudhi, "Pengaruh Gaya Kepemimpinan Transformasional dan Transaksional terhadap Kinerja Karyawan PT. ISS Indonesia di Rumah Sakit National Surabaya”, e-Jurnal Ilmu Manajemen, MAGISTRA, vo.1, no.1, 2015

Sonni, Joko Agustri, "Pengaruh Gaya Kepemimpinan Transformasional dan
Transaksional terhadap Kinerja Organisasi dengan Budaya Organisasi sebagai Variabel Pemoderasi (Studi Empiris Pada Perusahaan Perbankan Di Kota Padang)", Universitas Negeri Padang, 2013

Widodo, "Metodelogi Penelitian Manajemen", Fakultas Ekonomi Universitas Semarang", 2010

Yenny, "Prinsip-Prinsip Good Governance Studi Tentang Penerapan Prinsip-Prinsip Good Governance Dalam Pelaksanaan Pelayanan Publik di Kantor Camat Samarinda Utara Kota Samarinda", eJournal Ilmu Administrasi Negara, 2013

Yogi, "Pengaruh Gaya Kepemimpinan Transformasional terhadap Kepuasan Kerja melalui Kepercayaan pada Atasan PT. Catur Elang Perkasa kota Surabaya". Skripsi, Jurusan Manajemen, Program Studi S1-Manajemen Konsentrasi Manajemen Sumber Daya Manusia Fakultas Ekonomi Universitas Negeri Malang, 2011

Yulianti, Wuryanti, "Pengaruh Kepemipinan Transformasional, Integritas Perilaku dan Kepercayaan terhadap Pimpinan dalam Peningkatan Kinerja SDM (Studi BLHKP, BKPPD dan BPMP Kabupaten Konawe Selatan, Provinsi Sulawesi Tenggara)", Conference in Business, Accounting, and Management, vol.2, no.1, 2015

Zulkifli, Irawan, "Kepemimpinan Transformasional dalam Proses Penerimaan dan Proses Seleksi Pemimpin Publik dalam Menciptakan Kepercayaan Di Indonesia", Binus Business Review, vol. 4, no. 1, 2013 